\title{
STAPLERS IN DIGESTIVE SURGERY. Technological advancement in surgeons' own hands
}

Santo MA, Takeda FR, Sallum RAA. Staplers in digestive surgery. Technological advancement in surgeons' own hands. Arq Gastroenterol. 2011;48(1):1-2.

HEADINGS - Surgical staplings. Colorectal surgery. Digestive system surgical procedure.

In this current issue of ARQUIVOS de GASTROENTEROLOGIA a multicentric study with the use of mechanical suture in rectocele surgical correction is published ${ }^{(2)}$. The evolution of mechanical sutures by means of stapler use has become a real technological advancement process, as it has represented the concept of a new product with the combination of new functions that have resulted in improvements and effective gains of quality or productivity in the handicraft suture process that has been done by surgeons for centuries, particularly in visceral anastomoses.

Although the concept of minimally invasive surgery has come following the videolaparoscopic era, the effect of minimizing the operative trauma has certainly been the main attribute in the use of staplers, especially in the application in difficult access operative fields. The pioneer use of such devices in the pelvis, to reach the low rectum and, the esophagogastric junction, has allowed the association of two fundamental concepts in oncological surgery, radicality and possibility of organofunctional preservation, directly improving patients' evolution.

Ever since the beginning of stapler use in abdominal surgeries in mid-1908, with Victor Fischer and Hümér Hültl, and in 1924, with Petz Aladar ${ }^{(13)}$, the surgical procedure has become more practical and objective, despite higher costs. Currently, the employment of staplers in great surgical procedures has become a more and more often and necessary practices, mainly in more complex laparoscopic operations that might apply extensive resections and digestive reconstructions. Significant improvement in surgical results is then observed, due to the reduction of the operative time and lengthiness of hospitalization, with the evidence of reduction of complications, mostly in face of effective hemostasia and lower tissue trauma.

In the literature, the major studies and most of available high quality evidences describe the use of staplers in esophageal, gastric and colorectal resections, as there is a routine in their use. The evidence of literature shows that stapler anastomoses lead to a shorter operative time, although more expensive than the ones performed manually. As for morbidity rates and fistula occurrence, the results are similar or even better when compared to the manual technique. However, the proper use of staplers and the surgeons' experience remain as crucial issues to succeed in the use of such devices ${ }^{(8)}$, implying the necessity of combination of both clinic-surgical experience and technical training, providing regular systematization and standardization.

Clearly, the esophageal resections have been facilitated by those devices in making the gastric tube to be pulled through, as well as in the performance of intrathoracic or cervical anastomosis, without any difference in complications after esophagectomy, and shorter operative time in the mechanical anastomosis group $^{(5,14)}$.

The bariatric surgery maybe has been the subgroup of procedures that has more benefits with the use of staplers, mainly for provide the gastric section in a smallest possible space, in conventional or laparoscopic way ${ }^{(1)}$, making the procedure safer and feasible, specially with the arrival of the flexible tip staplers and special cartridges, with more stapling lines and different size of the cramps.

In the colorectal surgery, the stapler use has been provided lower anastomoses and in patients with clearly unfavorable anatomy, due the narrow pelvis. Many published meta-analyses concluded that there is no difference between conventional or stapled operation when compared about morbid-mortality ${ }^{(10)}$. However, same authors highlight the importance of the correct management of these devices, causing complications related to higher rates of morbidity and mortality in the inadequate technique of stapling procedure ${ }^{(12)}$. In colon's resection, staplers had long increased as well as laparoscopic approach, allowing its use in a large number of segments of the anastomoses with linear or circular staplers. Several randomized trials have demonstrated the effectiveness of the PPH (procedure for prolapsed and hemorroidopexy) (9) in the treatment of hemorrhoids ${ }^{(3,7)}$, and rectal prolapsed, with special attention to the selection of indications ${ }^{(2)}$. 
In pancreatic resections, staplers have benefit only in distal pancreatectomy ${ }^{(18)}$, although there is a discussion about the results in regular use or selected cases ${ }^{(16)}$. In hepatic surgery, the pioneered use of staplers occurred in vascular hepatic veins $^{(11)}$, and now the left lateral segment hepatectomy is preferably performed laparoscopically with the use of staplers for vascular ligation and section of the parenchyma ${ }^{(4,6,15)}$. Laparoscopic liver resections have become increasingly frequent in the last decade, including application in liver transplantation.

Thus, there is the prospect of using the mechanical suture in endoscopic procedures in the field of control of gastroesophageal reflux, some form of gastropexy for bariatric procedures in the treatment of obesity and also from the increment of the techniques through natural orifice.

The accumulated experience over all these decades of the use of staplers is a real manifestation of the association between the fields of surgical knowledge to the technological advancement carried out by technology companies.

Marco Aurelio SANTO Flavio Roberto TAKEDA Rubens A.A. SALLUM

Santo MA, Takeda FR, Sallum RAA. Suturas mecânicas em cirurgia digestiva. Inovação tecnológica nas próprias mãos do cirurgião. Arq Gastroenterol. 2011;48(1):1-2.

DESCRITORES - Grampeamento cirúrgico. Cirurgia colorretal. Procedimentos cirúrgicos do sistema digestório.

\section{REFERENCES}

1. Carbonell AM, Joels CS, Sing RF, Heniford BT. Laparoscopic gastric bypass surgery: equipment and necessary tools. J Laparoendosc Adv Surg Tech A. 2003; 13:241-5

2. Cruz JV, Regadas FSP, Murad-Regadas SM, Rodrigues LV, Benicio F, Leal R, Carvalho CG, Fernandes M, Roche LMC, Miranda AC, Câmara L, Pereira JC, Parra AM, Leal VM. TRREMS procedure (transanal repair of rectocele and rectal mucosectomy with one circular stapler) A prospective multicenter trial. Arq Gastroenterol. 2011;48:3-7.

3. Ganio E, Altomare DF, Gabrielli F, Milito G, Canuti S. Prospective randomized multicentre trial comparing stapled with open hemorrhoidectomy. Br J Surg. 2001;88:669-74.

4. Gumbs AA, Gayet B, Gagner M. Laparoscopic liver resection: when to use the laparoscopic stapler device. HPB (Oxford). 2008;10:296-303.

5. Hsu HH, Chen JS, Huang PM, Lee JM, Lee YC. Comparison of manual and mechanical cervical esophagogastric anastomosis after esophageal resection for squamous cell carcinoma: a prospective randomized controlled trial. Eur J Cardiothoracic Surg. 2004:25:1097-101.

6. Kaneko H, Takagi S, Otsuka Y, Tsuchiya M, Tamura A, Katagiri T, Maeda T, Shiba T. Laparoscopic liver resection of hepatocellular carcinoma. Am J Surg. 2005;189:190-4.

7. Khalil KH, O'Bichere A, Sellu D. Randomized clinical trial of sutured versus stapled closed hemorrhoidectomy. Br J Surg. 2000;87:1352-5.

8. Korolija D. The current evidence on stapled versus hand-sewn anastomoses in the digestive tract. Minim Invasive Ther Allied Technol. 2008;17:151-4.
9. Longo A. Treatment of hemorrhoidal disease by reduction of mucosa and hemorrhoidal prolapse with a circular-suturing device: a new procedure. In: Proceedings of the 6th World Congress of Endoscopic Surgery. Rome, Italy: 1998. Surg Endosc. 1998; 12 (5).

10. Lustosa SA, Matos D, Atallah AN, Castro AA. Stapled versus handsewn methods for colorectal anastomosis surgery: a systematic review of randomized controlled trials. Cochrane Database Syst Rev. 2001(3): CD003144.

11. McEntee GP, Nagorney DM. Use of vascular staplers in major hepatic resection. Br J Surg. 1991;78:40-1.

12. Offodile AC 2nd, Feingold DL, Nasar A, Whelan RL, Arnell TD. High incidence of technical errors involving the EEA circular stapler: a single institution experience. J Am Coll Surg. 2010;210:331-5.

13. Robicsek F. The birth of the surgical stapler. Surg Gynecol Obstet. 1980;150 $579-83$

14. Sallum RA, Coimbra FJ, Herman P, Montagnini AL, Machado MA. Modified pharyngogastrotomy by a stapler technique. Eur J Surg Oncol. 2006;32:540-3.

15. Shimada M, Hashizume M, Maehara S, Tsujita E, Rikimaru T, Yamashita T, Tanaka S, Adachi E, Sugimachi A. Laparoscopic hepatectomy for hepatocellular carcinoma. Surg Endosc. 2001;15:541-4.

16. Shukla PJ, Nagarajan G, Barretto SG. Use of staplers to divide the pancreas during pancreatoduodenectomy: is it justified? HPB (Oxford). 2009;11:90.

17. Urschel JD, Blewett CJ, Bennett WF, Miller JD, Young JE. Handsewn or stapled esophagogastric anastomoses after esophagectomy for cancer: meta-analysis of randomized controlled trials. Dis Esophagus. 2001;14:212-7.

18. Zhou W, Lv R, Wang X, Mou Y, Cai X, Herr I. Stapler vs suture closure of pancreatic remnant after distal pancreatectomy: a meta-analysis. Am J Surg. 2010;200:529-36. 